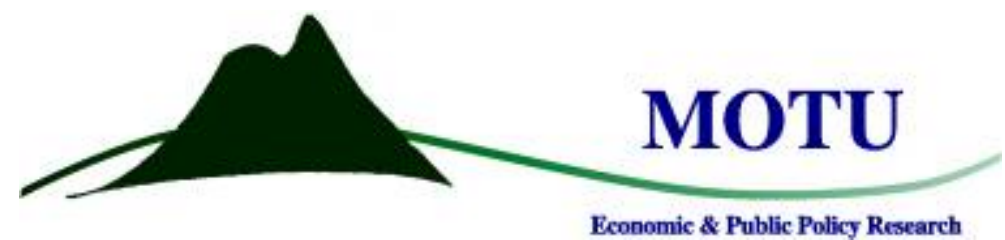

\title{
ALLOCATING RISKS IN A DOMESTIC GREENHOUSE GAS TRADING SYSTEM
}

\author{
Suzi Kerr \\ Motu Economic and Public Policy Research Trust \\ Working Paper \# 2003-01 ${ }^{1}$
}

March 2003

Suzi Kerr (suzi.kerr@motu.org.nz) is Director and a Senior Fellow of Motu. The United States Environmental Protection Agency through Resources for the Future funded early work on this paper. More recent work was Funded by the New Zealand Foundation for Research Science and Technology. I would like to thank Michael Toman for very helpful comments and Debara Parker for editing help. Any remaining errors and omissions are my responsibility.

\footnotetext{
${ }^{1}$ C) 2003 Motu Economic and Public Policy Research Trust. All rights reserved. No portion of this paper may be reproduced without permission of the authors. Motu working papers are research materials circulated by their authors for purposes of information and discussion. They have not necessarily undergone formal peer review or editorial treatment. ISSN 1176-2667.
} 


\section{ABSTRACT}

As tradeable permit programmes mature, two inter-related issues are becoming more critical in creating viable responses to a long-term, highly uncertain environmental problem such as climate change. First, we need to update policies in response to new information; and second, we need to design policies so that they can be updated without creating adverse strategic incentives for either government or regulated entities. Consideration of both exogenous risk (uncontrollable) and endogenous risk (concerns about policy credibility) suggests that permits should be auctioned several years in advance of use, and each permit should be defined as a percentage of a possibly varying target. For exogenous risks, this system allows all risk to be pooled and managed as efficiently as possible within the private sector. For endogenous risk, it creates a vested interest that will pressure government to maintain or strengthen targets to offset the obvious pressures to weaken regulation. It also reduces the ability of government to reallocate rents without cost to itself, or to gain revenue by altering targets. In addition, policy should be made as complete and as transparent as possible, and its key elements should be embedded in legislation to limit prospects for capricious changes in the future. 


\section{INTRODUCTION}

As tradeable permit programmes mature, two inter-related issues are becoming more critical in creating viable responses to a long-term, highly uncertain environmental problem such as climate change. First there is the need to update policies in response to new information; and second, there is the design of the programmes themselves (that is, do they contain processes for future adjustments in environmental targets as and when the need arises?) In those that do not, serious problems have arisen because changing permit allocations can be politically challenging if not built into programme design. ${ }^{2}$ For example, the New Zealand Individual Transferable Quota system had to change the definition of quota to facilitate changes in caps, ${ }^{3}$ while in the United States, vigorous debate continues on how to adjust the Acid Rain programme to achieve more stringent targets. ${ }^{4}$ This is an extremely important issue when addressing a long-term, highly uncertain environmental problem such as climate change.

An important part of the integrated assessment literature on climate change has focused on the nature of the "optimal" greenhouse gas reduction profile in the presence of uncertainties about damages, abatement costs, and discount factors. Other studies have followed the path blazed by Weitzman (1974) and considered how damage and cost uncertainty affect the choice of policy instrument, specifically the choice between price and quantity (tradeable permits) policies (Pizer, 1999; Newell and Pizer, 1999; Stavins, 1996). Another interesting literature has explored the effect of uncertainty on appropriate choices of long-term discount rate (Weitzman, 1998; Pizer and Newell, 2000).

In this paper we focus on the allocation of two major categories of risk between private entities and the government in a domestic trading system. The first, "exogenous" risks, are those that cannot be controlled by any party to the regulation. These include changes in abatement technology or scientific discoveries about climate change risks that alter optimal regulatory targets. The second, "endogenous" risks, are those that can be influenced by either the government or regulated entities. These usually manifest themselves by means of opportunistic policy change by the government and strategic behaviour (in investment or

\footnotetext{
${ }^{2}$ See in particular discussion of the allocation of water rights in Australia in Young (2003).

${ }^{3}$ See Straker et al (2002).

${ }^{4}$ See Ellerman (2003).
} 
lobbying) by regulated entities. Any such action by either or both parties can affect the intertemporal credibility of the regulatory bargain.

\section{EXOGENOUS SHOCKS}

Initially accepting the abatement targets as given, we focus on risks within a tradeable permit market designed to achieve those targets, particularly on the impacts of exogenous uncertainties on socially-optimal abatement investment responses, and the optimal allocation of the exogenous risks between the government and regulated entities (typically, the private sector).

While any distinction between exogenous and endogenous risks can be somewhat arbitrary, several factors are external to the operation of a Greenhouse Gas (GHG) trading system. These include natural events (cold winters that increase fossil fuel demand; natural disasters that reduce economic activity and damage infrastructure); changes in scientific knowledge about the severity of climate change risks; and socio-economic events such as changes in social preferences about the level of acceptable climate risk, macroeconomic fluctuations and trends, and broad technical progress in GHG abatement. The form and stringency of GHG policy will affect the latter two factors, but their inherent uncertainty are largely out of the control of both the government and the regulated entities. Some of these factors are short-term or cyclical (business fluctuations or weather shocks), while others (technical progress, improved climate risk assessment) are longer-term in their effect on trends in control cost, or the desired level of GHG control.

The socially-optimal response to these risks is multifaceted. First, information pertinent to these uncertainties should be collected and disseminated. Second, research and development (focusing on the reduction of uncertainties and the increase in options for GHG abatement) should be undertaken. Third, tangible investments will be needed to efficiently meet the GHG emission targets. The irreversibility of investment will bias the investment response toward slower and less capital-intensive actions. In contrast, convex costs of investment with regard to time will bias toward more rapid and more readily expandable investment as protection against the potential need for more stringent targets. At the aggregate level, society needs to be able to respond quickly, and at low cost, to more or less stringent targets. 
In a permit market, exogenous shocks play out in terms of the price of contracts (spot, forward, future, and option) for GHG permits. The imposition of significant regulatory constraints on fossil fuel use and GHG emissions creates scarcity rents worth tens, if not hundreds, of billions of dollars. Public and private holders of permit assets will experience capital gains when permit prices rise, while permit buyers will experience increased costs for covering their residual emissions. These asset and price risks are negatively correlated. At the same time, changes in the price of permits are likely to be pro-cyclical with regard to the economy, in that factors which reduce (increase) economic activity and demand for fossil fuels, might also reduce (increase) permit prices. ${ }^{5}$ These positively- and negatively-correlated risks can be efficiently spread throughout society through choices of private investment portfolios (including permit assets), derivatives in the permit market, and insurance.

Uncertainty also will affect technology choices. Investors will put a lower value on technology whose profitability is dependent on emissions targets being set at a certain level at a certain time. Firms will also see less value in technologies subject to obsolescence through innovation. Risks arising from idiosyncratic technology investments cannot be efficiently shared through society. Private information about the choice of projects, and the effort taken to implement them, creates moral hazard problems and precludes efficient risk-sharing. Agents that do make idiosyncratic investments will bear too much risk. Agents with little collateral will be risk-averse and invest less than society would like. Both will generate efficiency losses.

What is the appropriate role of government in implementing this portfolio of actions? We conclude that the government does not have a comparative advantage in bearing most of these risks, as opposed to having them borne by the private sector. Obviously the government does have a role in public goods provision, including the provision of information and activities to correct imperfections in the research and development market (for example, support for basic research that reduces uncertainty). Government also has a role in mitigating macroeconomic risks through the implementation of appropriate fiscal and monetary policies.

From the perspective of GHG policy, however, government cannot reduce the exogenous risks of shifts in climate change knowledge, social preferences, technical innovation, or international macroeconomic fluctuations. These risks also are correlated

\footnotetext{
${ }^{5}$ Interestingly this is not true for $\mathrm{SO}_{2}$ permits which are uncorrelated with market risk (i.e. their $\beta=0$ ).
} 
across the economy and are not "small" in relation to the overall scale of the economy, so the Arrow-Lind (1970) risk-pooling argument for government assumption of risk does not apply. Any large or permanent shock borne by government will ultimately be returned to the private sector through higher taxation, with taxation's additional costly distortion. Nor is it evident that government has a comparative advantage in providing insurance. The private sector can effectively establish a variety of risk-allocation mechanisms, including derivative transactions associated with GHG permit trading. The government has no comparative advantage in addressing moral hazard problems.

One role the government could play is distributional. Some groups have limited access to risk markets and potentially disproportionate exposure to climate change policy risks. These groups include workers who have technology-specific human capital (for example, coal miners, and low-income groups in general). However, other than supporting basic research and development, and possibly providing a safety net, the government does not have a comparative advantage in addressing exogenous risk.

What implications does the foregoing have for the design of a GHG trading system? It seems to us that the following points are pertinent:

- In concert with a trading policy, the government should support basic research and development and dissemination of information. The government also faces the difficult task of providing protection for more vulnerable parties in the economy, responding to distributional concerns. A variety of measures could be used, including increases in earned-income tax credits and/or job-retraining programmes. One of several arguments for auctioning GHG permits rather than issuing them gratis is that it provides a less distortionary way of financing such activities Cramton and Kerr (2002).

- One of the strengths of a permit trading system is that it provides a number of excellent ways in which the private sector can respond to short-term and cyclical risks. These include the accumulation and use of banked permits, as well as the establishment of derivatives markets. Government should do nothing to discourage these developments.

- Allocating permits denominated in fixed numbers of tons forces government to shoulder the risk of exogenous changes in future targets (for example, government must buy back excess permits if changes in knowledge or social preferences or drops in abatement cost lower the desired aggregate emissions target). To allocate more of this risk to the private 
sector, the government could allocate permits denominated as percentages of uncertain future targets to be determined subsequently. ${ }^{6}$

- While permit auctions have a number of virtues, if the government were to auction permits year-by-year, or for only a few years into the future, it would bear more of the asset risk associated with future changes in the prices of permits. To reduce this risk, the government could pursue longer-term allocation of permits. This would not violate the given short-term targets; these allocated permits could not be used before particular dates (as in the $\mathrm{US} \mathrm{SO}_{2}$ programme). The government could alternatively take positions in risk and insurance markets to reduce its risk, but allocating the asset risk to the private sector directly through longer-term permit allocations is more straightforward.

\section{Figure 1 Exogenous shocks, private responses and policy roles}

\begin{tabular}{|c|c|c|}
\hline Exogenous shocks & Responses to shocks & Policy Roles \\
\hline $\begin{array}{ll}\text { 1. } & \text { scale of abatement } \\
\text { required (new } \\
\text { scientific or cost } \\
\text { information) } \\
\text { 2. } \\
\text { technology } \\
\text { available }\end{array}$ & $\begin{array}{l}\text { Private Sector } \\
\text { 1. maintain options to expand and contract } \\
\text { - bias toward variable cost } \\
\text { - bias toward short lifetime investments } \\
\text { 2. delay investment } \\
\text { 3. pool risk } \\
\text { 4. research } \\
\text { 5. precautionary banking of permits }\end{array}$ & $\begin{array}{l}\text { 1. } \text { reduce risk through } \\
\text { research / learning } \\
\text { 2. allocate risk among } \\
\text { groups } \\
\text { - Advance } \\
\text { allocation of } \\
\text { permits } \\
\text { - Permit definition } \\
\text { e.g.: \% target }\end{array}$ \\
\hline
\end{tabular}

\section{ENDOGENOUS UNCERTAINTIES}

In real life, regulations can never take account of all possible contingencies. Future policy is always uncertain and subject to change. This opens up possibilities for postcontractual opportunistic behaviour on the part of regulated entities and/or the government. These possibilities are rendered more likely by the fact that a sovereign government cannot preclude opportunistic behaviour by itself or its successors in the future.

\footnotetext{
${ }^{6}$ For this approach to succeed, the private sector would have to have some confidence in the government's policy rule. We return to this point below in discussing endogenous risk. The government also would want to provide as much information as it could about the potential evolution of future targets in order for the private sector to rationally price these assets.
} 
Opportunistic behaviour by the government amounts to unilateral modification of the regulatory contract, as distinct from Pareto-improving renegotiation as a consequence of changes in circumstances. If the government changes the allocation of permits for political reasons, it burdens certain regulatees while benefiting others. Such changes would tend to arise from shifts in the political balance of power in respect of the stringency of GHG control, or the allocation of scarcity rents resulting from GHG limits.

Strategic unilateral modification of GHG policy by the government is problematic because it undermines the incentives for efficient investment by the private sector. If firms face increased uncertainty about climate policy objectives because of governmental capriciousness, their tendency to invest more slowly and in less capital-intensive actions in the face of exogenous risks will be unnecessarily magnified. ${ }^{7}$ Permit banking, and thus opportunities for intertemporal smoothing of abatement costs, will be unnecessarily limited if the risk of permit confiscation is seen as significant. Aside from these direct efficiency costs, strategic regulatory action by government also opens up new opportunities for costly rentseeking.

Private actors may behave opportunistically or strategically with regard to GHG policy. The most obvious strategy is under-investment (either in scale or pace over time), in the hope that relief from compliance could be negotiated later. The sought-for relief could be based on sectoral pleading (commonly observed in regulatory debates), or on the broader grounds that forcing costly compliance at the scale and pace stipulated in international GHG agreements would damage the economy as a whole. The latter puts future regulators in the position of choosing between non-compliance and recession.

Any single actor considering strategic under-investment must compare the costs of under-investment with the probability of regulatory relief. If actors seek aggregate relaxation of targets they compare the higher long-term costs of abatement resulting from their underinvestment if future targets are not relaxed, with the probability of negotiating a future

\footnotetext{
${ }^{7}$ Incentives to adopt new technology would similarly be weakened if the act of doing so triggered a capricious tightening of a sector's emissions obligations. This point must be handled with care, however, because a drop in abatement costs also is a legitimate rationale for the government to pursue tighter standards than it had previously (this is the point advanced, for example, by advocates of intertemporal flexibility in GHG abatement). The key question here is the capriciousness of government action in changing standards; what needs to be avoided is using the influx of a new technology to justify tougher standards whose benefits do not justify the costs, or actions that penalize specific sectors which signal lower costs through early adoption of new technology.
} 
relaxation in the targets and its expected value to them. If they are seeking benefits for their firm or sector, such as a greater share of future grandfathered permits, they compare the higher long-term costs of abatement that their under-investment generates with their expected capital gain through larger permit allocations. The probability of changing government policy depends on the political economy of sectoral pleading, and the probability that many other actors in the economy also would strategically under-invest, thus heightening the regulator's ex post environment/economy dilemma. ${ }^{8}$

How can these problems of governmental or private sector opportunism be addressed in the context of a permit trading system? Contract theory suggests three basic methods make contracts more complete; make renegotiation more costly; and reduce pressure to renegotiate. In considering these prescriptions, we must also keep in mind the practical difficulty of governments binding their successors. We therefore propose the following solutions:

- Spell out as clearly as possible the way that different contingencies are to be addressed. If permits are to be grandfathered, for example, the means by which this is to be done including dealing with entry and exit of firms - should be defined as precisely as possible, along with provisions for the sanctity of banked permits. While it is impossible in practice to spell out precisely the factors that would lead to changes in aggregate emissions targets, clarity in the rules for sectoral allocation will limit some key channels for ex post opportunism. This in turn would increase the longer-term credibility of the policy, enhancing the efficiency of investment and causing less discounting for uncertainty of future permit assets.

- Use an auction for allocating permits, not a gratis allocation formula. Many of the opportunities for governmental opportunism arise in connection with defining or redefining permit allocations. Powerful private-interest blocs can exercise influence to the exclusion of others in the negotiation over allocation formulas. These opportunities are precluded if an auction is used. To be sure, there still will be rent-seeking behaviour

\footnotetext{
${ }^{8}$ It would seem that strategically under-investing is not a dominant strategy. If one small set of actors did so but the bulk of the economy did not, this sector's pleading for special relief would be somewhat weakened and the prospects for economy-wide dislocation would be lower. This is especially true with permit trading, which affords them the chance to trade for lower-cost emission reductions elsewhere.
} 
in the use of auction revenues, but that is an established part of fiscal policy already; unlike gratis formula allocation, an auction does not create a new venue for rent-seeking.

- Make longer-term allocations of permits that are specified in terms of percentages of future targets thus creating a constituency that can oppose weakening of policy commitment. ${ }^{9}$ It also means that government cannot gain revenue by changing targets. Finally, establishing the design of the trading system in legislation will make it more difficult to make capricious changes in policy later.

- Establish the credibility of policy targets as well as policy measures ex ante. The latter can be fostered, for example, by establishing the trading mechanism before the beginning of the commitment period in 2008. The former requires enough social consensus about the goals of climate policy that large parts of the private sector will be deterred from strategic under-investment, because there is some assurance before the fact that society understands and is willing to bear the costs.

In conclusion, measures needed to address exogenous and endogenous risks in a GHG trading system are complementary. In both cases, clarity in the permit mechanism and allocation process and use of long-term allocation with banking seem warranted. Using permits denominated in shares of total emissions could create incentives for governments to raise revenue by making targets more stringent if permits are not allocated in advance. However, when combined with long-term allocation, this approach also seems to have merit. A bigger challenge may arise in reconciling the advantages of inter-temporal flexibility in responding to long-term climate targets under uncertainty, and the problems of deterring strategic under-investment or governmental shirking. Here again, a long-term allocation creates some countervailing pressure against opportunistic future relaxation of standards (as does technical progress that reduces future control costs).

Auctioning permits defined as a percentage of the target in advance has implications for innovation incentives. The returns from innovation are initially captured within the private sector, but not necessarily by the innovator. With advance allocation of permits, innovators can capture the "emissions payment" effect, which arises from the fall in permit

\footnotetext{
${ }^{9}$ If the demand for permits is price-inelastic (because of a steep marginal abatement cost schedule), then increasing total emissions with pro-rata emissions shares would give permit holders more absolute emissions but would drive down the price per unit of emissions by more. This approach would not make the government bear directly the costs of an emissions-target reduction, but it would not gain any revenue either and it would indirectly bear costs by responding to greater private sector burdens.
} 
price they induce, by holding permits short. If the target is made more stringent in response to the lower costs, the private sector receives any benefits from this through higher asset prices as well as bearing the higher abatement costs, in the same way that exogenous shocks are borne.

Figure 2 Endogenous shocks, possible renegotiation, private responses, and potential policy roles

\begin{tabular}{|c|c|c|c|c|}
\hline $\begin{array}{l}\text { Causes of } \\
\text { Endogenous } \\
\text { shocks }\end{array}$ & $\begin{array}{l}\text { Possible forms } \\
\text { of renegotiation }\end{array}$ & $\begin{array}{l}\text { Private } \\
\text { Responses }\end{array}$ & $\begin{array}{l}\text { Government } \\
\text { Policy Responses }\end{array}$ & \\
\hline $\begin{array}{ll}\text { 1. } & \text { incomplete } \\
\text { contract } \\
\text { 2. } \\
\text { Government } \\
\text { inability to } \\
\text { commit } \\
\text { - time } \\
\text { inconsistency } \\
\text { - change in } \\
\text { vested } \\
\text { interests } \\
\text { - information } \\
\text { revealed by } \\
\text { private actors }\end{array}$ & $\begin{array}{l}\text { 1. change target } \\
\text { 2. change } \\
\text { allocation } \\
\text { method } \\
\text { - auction vs. } \\
\text { gratis } \\
\text { - distribution of } \\
\text { gratis among } \\
\text { private actors } \\
\text { change } \\
\text { definition of } \\
\text { permits } \\
\text { 4. confiscate } \\
\text { existing } \\
\text { permits }\end{array}$ & 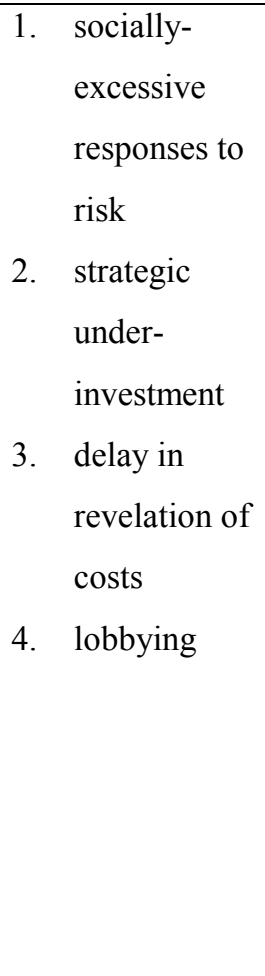 & $\begin{array}{l}\text { Directly reduce } \\
\text { probability of } \\
\text { renegotiation } \\
\text { 1. write more } \\
\text { complete } \\
\text { contract } \\
\text { 2. make } \\
\text { renegotiation } \\
\text { more costly } \\
\text { 3. initially } \\
\text { distribute costs } \\
\text { fairly } \\
\text { 4. create regular } \\
\text { policy reviews }\end{array}$ & $\begin{array}{l}\text { Reduce Scope of } \\
\text { Renegotiation } \\
\text { 1. auction } \\
\text { permits } \\
\text { 2. avoid political } \\
\text { advantage } \\
\text { from } \\
\text { reallocation } \\
\text { 3. avoid revenue } \\
\text { benefits from } \\
\text { target change } \\
\text { 4. strengthen } \\
\text { permit holders } \\
\text { 5. increase legal } \\
\text { protection of } \\
\text { permits }\end{array}$ \\
\hline
\end{tabular}

\section{SUMMARY}

Consideration of both exogenous risk (uncontrollable) and endogenous risk (concerns about policy credibility) suggests that permits should be auctioned several years in advance, and each permit should be defined as a percentage of a possibly varying target. For exogenous risks, this system allows all risk to be pooled and managed as efficiently as possible within the private sector. For endogenous risk, it creates a vested interest that will pressure government to maintain or strengthen targets to offset the obvious pressures to weaken regulation. It also reduces the ability of government to reallocate rents without cost to itself, or to gain revenue by altering targets. In addition, policy should be made as complete and as transparent as 
possible, and its key elements should be embedded in legislation to limit prospects for capricious changes in the future.

\section{REFERENCES}

Arrow, Kenneth. J. and Robert. C. Lind (1970) "Uncertainty and the Evaluation of Public Investment Decisions", American Economic Review, 60:364-378.

Cramton, Peter and Suzi Kerr (2002) "Tradeable Carbon Permit Auctions: How and Why to Auction not Grandfather", Energy Policy, 30: 333-345.

Ellerman, A. Denny (2003) "Ex Post Evaluation of Tradable Permits: The U. S. SO2 Capand-Trade Program" Paper prepared for OECD Workshop on Ex Post Evaluation of Tradable Permits: Methodological and Policy Issues.

Newell, Richard and William A Pizer (1999) "Regulating Stock Externalities Under Uncertainty", RFF Discussion Paper 99-10. Forthcoming Journal of Environmental Economics and Management.

Newell, Richard and William A Pizer (2000) "Discounting the Distant Future: How Much Do Uncertain Rates Increase Valuations?”, RFF Discussion Paper 00-45.|

Pizer, William A (1999) "Optimal Choice of Climate Change Policy in the Presence of Uncertainty", Resource and Energy Economics, 21: 255-287.

Stavins, Robert N (1996) "Correlated Uncertainty and Policy Instrument Choice", Journal of Environmental Economics and Management 30, 218-232.

Straker, Gina., Kerr, Suzi, and Hendy, Jo (2002) “A Regulatory History of New Zealand's Quota Management System" Chapters 1-4. www.motu.org.nz/nz_fish.htm

Weitzman, Martin L (1974) “Prices vs. Quantities” Review of Economic Studies 41.

Weitzman, Martin L (1998) "Why the Far-Distant Future Should Be Discounted at Its Lowest Possible Rate" Journal of Environmental Economics and Management 36(3): 201-208.

Young, Michael D (2003) "Learning from the Market: Ex-post Water Entitlement and Allocation Trading Assessment Experience in Australia" Paper prepared for OECD Workshop on Ex Post Evaluation of Tradable Permits: Methodological and Policy Issues. 